\title{
A Cross Sectional Analysis of Familial Alienation of Transgender: With Reference to District Swat-Pakistan
}

\author{
Atta Ullah ${ }^{1}$, Akhtar Ali ${ }^{2}$, Younas Khan ${ }^{3 *}$ \\ ${ }^{1}$ Mphil Scholar, Department of Rural Sociology, the University of Agriculture Peshawar, Pakistan \\ ${ }^{2}$ Assistant Professor, Department of Rural Sociology, the University of Agriculture Peshawar, Pakistan \\ ${ }^{3} \mathrm{PhD}$ Scholar, Department of Rural Sociology, the University of Agriculture Peshawar, Pakistan
}

\begin{abstract}
DOI: $10.36348 /$ SJHSS.2019.v04i10.007
| Received: 19.10 .2019 | Accepted: 26.10.2019 | Published: 30.10.2019
\end{abstract}

*Corresponding author: Younas Khan

\section{Abstract}

The major objective of the present study was to find out the familial alienation of transgender with reference to District Swat-Pakistan. A sample size of 210 respondents was selected from total population 400 as per Sekeran criteria. The data was collected through interview schedule and analyzed by using descriptive statistics frequency and percentage) and inferential statistics (Chi-square test) to find out the association between transgender (Dependent variable) and familial alienation (Independent variables). The results showed that a highly significant association $(\mathrm{P}=0.000)$ was found between "Transgender" \& "Familial Alienation" indicators; transgender often deal with gender disparity; transgender faced physical and psychological violence from family members; family members do not permit transgender to meet with other transgender along with transgender were killed in the name of honor. The study concluded that, family as an institution was found in total disarray with reference to performing its basic role pertaining to transgender. A comprehensive plan of action based on protecting them by introducing laws pertaining to their protection at macro and micro level specifically at family level is the order of the day were put forwarded some of the recommendations in the light of present study.

Keywords: Family, Alienation, Transgender, District Swat, KPK-Pakistan.

Copyright @ 2019: This is an open-access article distributed under the terms of the Creative Commons Attribution license which permits unrestricted use, distribution, and reproduction in any medium for non-commercial use (NonCommercial, or CC-BY-NC) provided the original author and source are credited.

\section{INTRODUCTION}

In English language the word Eunuchs used for "Tran's" which is derived from Greek word "Eune' which means bed and 'Ekhein' which means to keep, the combining means is "Bed Keeper'[1]. Mostly known as Khwaja Sira, albeit with many pejorative variants for their personal and social identity, transgender persons have long been a vulnerable group in Pakistan.

Unlike the narrow understanding of a transgender person in terms of biological anomalies, World Health Organization (WHO) defines this state of gender as: "Transgender is an umbrella term for people whose gender identity and expression does not conform to the norms and expectations traditionally associated with the sex assigned to them at birth; it includes people who are transsexual, transgender or otherwise considered gender non-conforming"*1. Tran's is "Vast" word which indicates those people who are different by sexual characters as well behaviorally from other members of the society by birth or socially and physically converted [2]. Likewise, transgender is a person who's personal and gender identity is not confirmed and contradicting with female or male gender. Transgender actually means an individual who is not completely female or male. It means that this specific type of people belongs to a third gender which is known as transgender [3].

Transgender is excluded since the dawn of history. There are so many Islamic countries around the globe whereas, Pakistan is one of them. Shari laws encouraging and supporting equal rights for all humans while according to media reports and surveys founded that Pakistani state itself along with other Nongovernmental Organizations (NGOs) they're ignoring transgender rights, which is against the Islamic and human rights laws [4]. Third genders have prominent role in our social life particularly in ceremonies, likewise engagements, weddings, birthday's parties and some rituals. Beside this, there are so many different names which are used for transgender in our Pakistani society like Murata, Khawaja Sara, Khusra etc 
(negative labeling names). Due to lack of education and conservatism third genders are considering extremely low class of the society and there is zero level of acceptance in Pakistani society in terms of social, economic and political affairs particularly. Furthermore, according to survey report third gender sex is about one-third of 50 children are noticed with Trans characteristics while almost 2 percent population of Pakistan is incline towards trans-phobia[5].

However, while going to work in the field amongst transgender of Hyderabad it has been discovered that amidst the Mughal era i.e., 1526 to 1857 when Hyderabad was considered as a princely state, the Hijras had been employed to watch over the harem, and treated as the servants in the nobility and some went through stages to become key advisors. It was noted in the modern era that they are considerably excluded from the very mainstream of the society. Some of the historians reported that, the responsibility and duty of transgender as court officials decreased considerably by the very end of the Mughal regime. Upon the downfall of the regime of Mughals what happened to the royal eunuchs is uncertain, though the oral history of Khwaja Sira suggests that they either got forwarded to establish a network of Hijra or were integrated. However, there is a considerable dissimilarity between contemporary and medieval Khwaja Siras, a very clear disparity which will obviously become unequivocal. In India the Colonial eunuchs were targeted and arrested by the order or discrimination applied by the British rulers $[6,7]$.

Third genders are more oriented towards female characters. From childhood they like to play with dolls and wearing females cloths. Those kinds of behaviors and actions are not acceptable to family. If a Trans cannot avoid these behaviors, in a result they face physical and psychological violence from family member. Those family which have trans people cannot give them respect and considering them characterless while as concern trans with in family, family members felt ashamed on him/her as being a part of house member. Particularly in sibling more reactions come from brothers in different violent forms. There are many stories of transgender that show us that Trans consider a symbol of disrespect and shame. That's why he/she kick out from home [8]. Moreover, oppression comes from male members of the family. Mother and sisters are very polite and closed to Tran's even they treat all children with gender equality. In Khyber Pukhtunkhawa the situations are varies third genders are kick out and killed in the name of honor and ashamed [9].

Trans-phobia can be define that a person or group of people having harsh and negative attitudes towards third gender because of his/her sex. Tansphobic people are criticising, blaming, alienating and considering Trans a sign of shame and disrespect.
Trans-phobic mentality is promoting by our cultural norm and printing and electronic media in society. A person's practices of trans-phobia can be aggravated due to religious, division, financial conditions [10]. At familial affairs from childhood transgender were treated badly in terms of, verbal abuse and physical violence which resulted negatively affects their self-esteem and get insight into an alienated personality in future. According to the record of Trans Murder Monitoring Project that about 1,700 Trans were killed in the period of 2008 to 2014 due to trans-phobic attitudes. In United States of America in 2013 three-quarter of homosexual, bisexual, Trans were killed and most of them were Trans [11]. As mentioned in the above literature the researchers were think to add a new addition to the existing stock of knowledge, to highlight the different attributes which caused familial alienations of transgender along with to give policy recommendations to eliminate the trans-phobic attitudes.

\section{MATERIAL AND METHODS}

The universe of the study was Atharabad Barn, Mingora city, District Swat, Khyber Pukhtunkhwa, Pakistan. The statistics of transgender population in the study area as per census report of Pakistan 2017 is negligible amount which is up to 50 only. Therefore as per pilot survey which was conducted by the researchers in August-2018 explored that, the total population of transgender in the study area were 400 thus, resulting 210 sample sizes as taken as per Sekeran criteria of sample size. The study was cross sectional design as well as five percent confidence interval was used to test error. Furthermore, a wellstructured and closed ended interview schedule was used for data collection because most of the respondents of the study area were illiterate. The data was encoded in the SPSS (20.0 version). Where UniVariate and $\mathrm{Bi}-$ Variate analysis along with to test the association between dependent and independent variable Chi-square (outlined by McCall and Robert 1975 test was used was used by using the following formula through indexation.

$$
\chi^{2}=\sum_{i=1}^{r} \sum_{j=1}^{c} \frac{\left(O_{i j}-e_{i j}\right)^{2}}{e_{i j}}
$$

Where, " $\mathrm{o}_{\mathrm{jk}}$ " was the observed frequency in the cell corresponding to the intersection of the $\mathrm{J}_{-}^{\text {th }}$ row and $\mathrm{K}$ th column, " $\mathrm{r}$ " the number of rows "c" the number of columns.

Table-1: Conceptual Framework

\begin{tabular}{|l|l|}
\hline Independent Variables & Dependent Variable \\
\hline Familial Alienation & Transgender \\
\hline
\end{tabular}

\section{RESULTS AND DISCUSSIONS}

Frequency Distribution and percentage of the respondents on the basis of Familial Alienation of Transgender 
Table No.2 highlighted the frequency and percentage distribution of family and alienation of transgender. The result shows that majority $50.0 \%$ of the respondents were stated that transgender are often dealt with gender disparity. This statement is supported by the report of National Gay and Lesbian Task Force [10]. Moreover, majority of the respondents $69.0 \%$ were agreed that the transgender are considered is a symbol of disrespect and shame generally while in family particularly. This statement is supported by the findings of Khan [14]. Likewise, majority $64.8 \%$ of the respondents were agreed that transgender faced physical and psychological violence from family members. This statement is also supported by the findings of preceding authors. Furthermore, $76.7 \%$ of the respondents agreed that transgender faced oppression from male members of the household. This statement is narrated by Khan [9]. Likewise, majority $55.2 \%$ of the respondents agreed that, transgender consistently sexually abused and humiliated in indoor and outdoor environment. This statement is supported by the findings of Malik [14]. In addition, $50.5 \%$ of the respondents were agreed that Transgender have no primary (family) relationship structure which is the reason of their alienation; $31.0 \%$ were not agreed, while $18.5 \%$ were have no information about this. The above statement is supported by Kamran [2]. Furthermore, $74.3 \%$ of the respondents were agreed that transgender are forced by family members to change their female to male members behaviors and attitudes due to patriarchal norms. As disclosed by Cohen [12]. Moreover, $52.4 \%$ of the respondent responded that the transgender felt suffocation in family environment. This statement is supported by the work of Khan [9]. Furthermore, majority $88.6 \%$ of the respondents were in the favor that, family does not permit transgender to meet with other transgender. These findings are similar with Khan [11]. Likewise, $54.8 \%$ of the respondents agreed that mostly transgender were killed in the name of honor and shamed. These findings are similar with Danila et al. [13].

Table-2: Frequency \& percentage distribution of the respondents on the basis of Familial Alienation of Transgender

\begin{tabular}{|c|c|c|c|c|c|}
\hline $\begin{array}{l}\text { S. } \\
\text { No }\end{array}$ & Statements & Yes & No & Uncertain & Total \\
\hline 1 & $\begin{array}{c}\text { Transgender is often dealt with gender disparity in familial } \\
\text { affair. }\end{array}$ & $105(50.0)$ & $45(21.4)$ & $60(28.6)$ & $210(100.0)$ \\
\hline 2 & $\begin{array}{l}\text { Transgender is considered a symbol of disrespect and } \\
\text { shame generally in public while in family particularly. }\end{array}$ & $145(69.0)$ & $47(22.4)$ & $18(8.6)$ & $210(100.0)$ \\
\hline 3 & $\begin{array}{l}\text { Transgender faced oppression from male members of the } \\
\text { household. }\end{array}$ & 161(76.7) & $7(3.3)$ & $42(20.0)$ & $210(100.0)$ \\
\hline 4 & $\begin{array}{l}\text { Transgender faced physical and psychological violence } \\
\text { from family members. }\end{array}$ & $136(64.8)$ & $39(18.6)$ & $35(16.6)$ & $210(100.0)$ \\
\hline 5 & $\begin{array}{l}\text { Transgender consistently sexually abused and humiliated } \\
\text { in indoor and outdoor environment. }\end{array}$ & $116(55.2)$ & $33(15.7)$ & $61(29.1)$ & $210(100.0)$ \\
\hline 6 & $\begin{array}{l}\text { Transgender have no primary (family) relationship } \\
\text { structure which is the reason of their alienation. }\end{array}$ & $106(50.5)$ & $65(31.0)$ & $39(18.5)$ & $210(100.0)$ \\
\hline 7 & $\begin{array}{l}\text { Transgender are forced by family members to change their } \\
\text { female to male, behaviours and attitude due to patriarchal } \\
\text { norms. }\end{array}$ & $156(74.3)$ & $7(3.3)$ & $47(22.4)$ & $210(100.0)$ \\
\hline 8 & Transgender feel suffocated in family environment. & $110(52.4)$ & $31(14.8)$ & $69(32.8)$ & $210(100.0)$ \\
\hline 9 & $\begin{array}{l}\text { Family does not permit Transgender to meet with other } \\
\text { transgender. }\end{array}$ & $186(88.6)$ & $8(3.8)$ & $16(7.6)$ & $210(100.0)$ \\
\hline 10 & Transgender is killed in the name of honour and shamed. & $115(54.8)$ & $71(33.8)$ & $24(11.4)$ & $210(100.0)$ \\
\hline \multicolumn{6}{|c|}{$\begin{array}{c}\text { Note: Values in the table present frequency while in the parenthesis represents percentage (\% age) of the } \\
\text { respondents. }\end{array}$} \\
\hline
\end{tabular}

\section{The Association between Familial Alienation and Transgender}

Table no 3 disclosed the association between dependent ${ }^{\text {\{transgender\} }}$ and independent variable $\{$ Familial Alienation\} through using indexation method by the virtue of chi-square test. The results are shown as below:

A significant level of the association $(\mathrm{P}=0.00)$ was found between transgender having no acceptance in their familial life, they are deal with alienation and exploitations. Family are not giving equal importance as like other members of the household while such kind of actions and attitudes towards Trans makes them more alienated. According to The National Centre for transgender Equality report and The National Gay and Lesbian Task Force reported on the name of "Injustice at Every Turn" explain that 6,500 trans sample were exploited and marginalized in their walk of life, likewise in family affairs, politics, jobs and recruitment, health and securities[10].

Additionally, a highly significant association $(\mathrm{P}=0.000)$ was found between Transgender is considered a symbol of disrespect and shame generally 
in public while in family particularly with transgender. Jami et al. narrated that third gender having dual personality. In case of Tran's women, actually they are male by birth but they are behaving like women and Tran's men, they are actually female at birth time but they pretended like male. Further, the behaviors and manners of Tran's men and Tran's woman are not encouraged in familial and social environment. In social life people criticizing and considering it symbol of disrespect and shame. Tran's woman and Tran's men are facing problems and difficulties from their families as well from their surroundings. Moreover, family members are forcing them to change their behaviors to actual they are and they are doing physical and psychological violence with transgender. In last Trans were kicked out form their families. Most of the Trans are agreed with that the violence comes from male members of the family [9]. Furthermore, a highly significant $(\mathrm{P}=0.000)$ level of association was found between transgender faced physical and psychological violence from family members and transgender. This statement is also supported by the finding of the proceeding author [9].

Likewise, a highly signification $(\mathrm{P}=0.000)$ association was found between transgender faced oppression from male members of the household and transgender. This statement is also disclosed by Khan, that Tran's are facing different types of suppressions and oppressions from the side of their family members. Furthermore, as compared to female members, male members of the house are deal third gender with harsh attitudes and making them suppress even they don't allow third gender to live there life by their own choices. Beside, female members of the household, they are very polite, friendly and sympathetic with transgender. The discouragement and oppression of family members leads to high level of social exclusion of transgender [11].

The data further revealed that the association between transgender consistently sexually abused and humiliated in indoor and outdoor environment with transgender. A highly significant $(\mathrm{P}=0.000)$ level of association was found between both variables. This statement is supported by the findings of Malik disclosed that khawa saira were living miserable life in their family and out of family. They're sexual abused and harassed during working places and particularly in educational institutions; students are passing comments and bullying and same like their daily life. They are threatening in the form of sexual abusing make them more excluded [14]. Likewise, the result shown the highly significant $(\mathrm{P}=0.000)$ level of association between transgender have no primary (family) relationship structure which is the reason of their alienation and transgender. This statement is supported by Kamran, dismantled that, third gender has no primary relations with families because their relative and brothers don't like his/her ambiguous personality. Further, mostly they are leaving their home for the sack of life survival. Family member are not the favor of the Trans to live with them and they're not agreed with third gender to expect his/her ambiguous personality [2].

Moreover, the data shown the association between Transgender are forced by family members to change their female to male, behaviors and attitude due to patriarchal norms and transgender while highly significant $(\mathrm{P}=0.000)$ level of association was found between both variables. As Cohen narrated that, Tran's men and Tran's women are facing problems due his feminine or masculine behaviors. Family members are stressing on them to change their manners while in most cases Trans were not agreed while for manners and behaviours changing family using different ways, in forms of physical and psychological violence [12]. The results shown the association between Transgender feel suffocated in family environment and Transgender. The association between both variable was found highly significant $(\mathrm{P}=0.000)$. Trans were felt suffocation in their familial life because of strictness in their life. They're unable to interact with other person like him/her. Parents want them limited to family sphere even Tran's moment are under the control of their family. Such types of restrictions make them more suffocated all the times. Furthermore, more time they're spending within family which makes her/his life more boring and a sense of insecurity [9].

The association between family does not permit Transgender to meet with other transgender and third gender was found highly significant $(\mathrm{P}=0.000)$. These findings are similar with Khan. $\mathrm{F}$ stated that, the strict familial norms and cultural doesn't allow transgender to meet with other individuals while particularly other third genders. Tran's are cannot out from their homes for the sake of entertainment and refreshment because of their familial checks and regulation. In addition, one of transgender were interviewed to the Khan that, when I come close to transgender in my town specially daily bases interaction with them as a result my family stop me to talk with them even they did physical violence with me to make me suppressed[11]. Furthermore, the results shown the association between transgender is killed in the name of honor and shamed and transgender. A highly significant $(\mathrm{P}=0.000)$ level of the association was found in both variables. Daniela et al. Dismantled that, transgender are unsafe in familial life. In Khyber Pukhunkhawa they're concern with serious security threats with in family in external affairs. Sometime Tran's are facing server kind of physical violence which leading to death. Moreover, most of the respondents were killed by their family on the name of honor and still many of Tran's been threaten by their relative [13]. 
Atta Ullah et al; Saudi J. Humanities Soc Sci, Oct 2019; 4(10): 678-683

Table-3: The Association between Familial alienation and Transgender

\begin{tabular}{|c|c|c|c|c|c|c|c|}
\hline \multicolumn{3}{|c|}{ Familial Alienation } & \multicolumn{4}{|c|}{ Transgender } & \multirow[b]{2}{*}{$\begin{array}{l}\text { Chi- } \\
\text { Square }\end{array}$} \\
\hline S\# & Statements & Attitudes & Yes & No & Uncertain & Total & \\
\hline \multirow[t]{3}{*}{1} & \multirow[t]{3}{*}{ Transgender is often dealt with gender disparity. } & Yes & $93(44.3)$ & $12(5.7)$ & $0(0.0)$ & $105(50.0)$ & \multirow{3}{*}{$\begin{array}{l}x^{2}=89.082 \\
P=(0.000)\end{array}$} \\
\hline & & No & $25(11.9)$ & $16(7.6)$ & $4(1.9)$ & $45(21.4)$ & \\
\hline & & Uncertain & $11(5.2)$ & $29(13.8)$ & $20(9.5)$ & $60(28.6)$ & \\
\hline \multirow[t]{3}{*}{2} & \multirow{3}{*}{$\begin{array}{l}\text { Transgender is considered a symbol of disrespect and } \\
\text { shame generally in public. }\end{array}$} & Yes & $123(58.6)$ & $22(10.5)$ & $0(0.0)$ & $145(69.0)$ & \multirow{3}{*}{$\begin{array}{l}x^{2} \\
=127.896 \\
\mathrm{p}=(0.000)\end{array}$} \\
\hline & & No & $0(0.0)$ & $27(12.9)$ & $20(9.5)$ & $47(22.4)$ & \\
\hline & & Uncertain & $6(2.9)$ & $8(3.8)$ & $4(1.9)$ & $18(8.6)$ & \\
\hline \multirow[t]{3}{*}{3} & \multirow{3}{*}{$\begin{array}{l}\text { Transgender faced oppression from male members of the } \\
\text { household. }\end{array}$} & Yes & $125(59.5)$ & $36(17.1)$ & $0(0.0)$ & $161(76.7)$ & \multirow{3}{*}{$\begin{array}{l}x^{2} \\
=138.407 \\
P=(0.000)\end{array}$} \\
\hline & & No & $0(0.0)$ & $0(0.0)$ & $7(3.7)$ & $7(3.3)$ & \\
\hline & & Uncertain & $4(1.9)$ & $21(10.0)$ & $17(8.1)$ & $42(20.0)$ & \\
\hline \multirow[t]{3}{*}{4} & \multirow{3}{*}{$\begin{array}{l}\text { Transgender faced physical and psychological violence } \\
\text { from family members. }\end{array}$} & Yes & $166(50.5)$ & $30(14.3)$ & $0(0.0)$ & $136(64.8)$ & \multirow{3}{*}{$\begin{array}{l}x^{2} \\
=139.843 \\
\mathrm{P}=(0.000)\end{array}$} \\
\hline & & No & $23(11.0)$ & $15(7.1)$ & $1(0.5)$ & $39(18.6)$ & \\
\hline & & Uncertain & $0(0.0)$ & $12(5.7)$ & $23(11.0$ & $35(16.7)$ & \\
\hline \multirow[t]{3}{*}{5} & \multirow{3}{*}{$\begin{array}{l}\text { Transgender consistently sexually abused and humiliated } \\
\text { in indoor and outdoor environment. }\end{array}$} & Yes & $100(47.6)$ & $16(7.6)$ & $0(0.0)$ & $116(55.2)$ & \multirow{3}{*}{$\begin{array}{l}x^{2} \\
=93.1142 \\
\mathrm{P}=(0.000)\end{array}$} \\
\hline & & No & $0(0.0)$ & $21(10.0)$ & $12(5.7)$ & $33(15.7)$ & \\
\hline & & Uncertain & $29(13.8)$ & $20(9.5)$ & $12(5.7)$ & $61(29.0)$ & \\
\hline \multirow[t]{3}{*}{6} & \multirow{3}{*}{$\begin{array}{l}\text { Transgender have no primary (family) relationship } \\
\text { structure which is the reason of their alienation. }\end{array}$} & Yes & $98(46.7)$ & $8(3.8)$ & $0 .(0.0)$ & $106(50.5)$ & \multirow{3}{*}{$\begin{array}{l}x^{2}=89.912 \\
\mathrm{P}=(0.000)\end{array}$} \\
\hline & & No & $21(10.0)$ & $31(14.8)$ & $13(6.2)$ & $65(31.0)$ & \\
\hline & & Uncertain & $10(4.8)$ & $18(8.6)$ & $11(5.2)$ & $39(18.6)$ & \\
\hline \multirow[t]{3}{*}{7} & \multirow{3}{*}{$\begin{array}{l}\text { Transgender are forced by family members to change } \\
\text { their female to male, behaviours and attitude due to } \\
\text { patriarchal norms. }\end{array}$} & Yes & $100(47.6)$ & $39(18.6)$ & $17(8.1)$ & $156(74.3)$ & \multirow{3}{*}{$\begin{array}{l}x^{2} \quad= \\
29.780 \\
P=(0.000)\end{array}$} \\
\hline & & No & $0(0.0)$ & $2(1.0)$ & $5(2.4)$ & $7(3.3)$ & \\
\hline & & Uncertain & $29(13.8)$ & $16(7.6)$ & $2(1.0)$ & $47(22.4)$ & \\
\hline \multirow[t]{3}{*}{8} & \multirow[t]{3}{*}{ Transgender feel suffocated in family environment. } & Yes & $98(46.7)$ & $12(5.7)$ & $0(0.0)$ & $110(52.4)$ & \multirow{3}{*}{$\begin{array}{l}x^{2}=95.381 \\
\mathrm{P}=(0.000)\end{array}$} \\
\hline & & No & $2(1.0)$ & $16(7.6)$ & $13(6.2)$ & $31(14.8)$ & \\
\hline & & Uncertain & $29(13.8)$ & $29(13.8)$ & $11(5.2)$ & $69(13.29)$ & \\
\hline \multirow[t]{3}{*}{9} & \multirow{3}{*}{$\begin{array}{l}\text { Family does not permit Transgender to meet with other } \\
\text { transgender. }\end{array}$} & Yes & $126(6.0)$ & $48(22.9)$ & $12(5.7)$ & $186(88.6)$ & $x^{2}=64.739$ \\
\hline & & No & $0(0.0)$ & $1(0.5)$ & $7(3.3)$ & $8(3.8)$ & $\mathrm{P}=(0.000)$ \\
\hline & & Uncertain & $3(1.4)$ & $8(3.8)$ & $5(2.4)$ & $16(7.6)$ & \\
\hline 10 & Transgender is killed in the name of honour and shamed. & Yes & $100(47.6)$ & $15(7.1)$ & $0(0.0)$ & $115(54.8)$ & $x^{2}$ \\
\hline & & No & $29(13.8)$ & $38(18.1)$ & $4(1.9)$ & $71(33.8)$ & $=183.239$ \\
\hline & & Uncertain & $0(0.0)$ & $4(1.9)$ & $20(9.5)$ & $24(11.4)$ & $\mathrm{P}=(0.000)$ \\
\hline
\end{tabular}

\section{CONCLUSION AND RECOMMENDATIONS}

The current study watches over the familial alienation of transgender in district Swat, Khyber Pukhtunkhwa Pakistan. The study concluded that, family as an institution was found in total disarray with reference to performing its basic role pertaining to transgender. Transgender often were dealt with gender disparity in most of the affairs both at micro and macro level. Transgender were considered a symbol of disrespect and shame, thus rendering them vulnerable to extreme oppression from male members along with transgender may kill in the name of honor and respect. Thus, comprehensive plan of action based on protecting them by introducing laws pertaining to their protection at macro and micro level specifically at family level is the order of the day were recommended some of the recommendations in the light of present study.

\section{REFERENCE}

1. Mariam Webster Dictionary, 'Eunuch'. Retrieved from: webster.com/dictionary/eunuch https://www.merriam-

2. Kamran, S., \& Intikhab, A. (2017). Transgender Issues in Pakistani Community. European Academic Research. Vol. IV, Issue 10 Retrieved from

https://www.researchgate.net/publication/31411638 1_Transgender_Issues_in_Pakistani_Community
3. Valentine, D. (2007). Imagining Transgender: An Ethnography of a Category. Duke

4. Akhtar, M. (2016, April 20). Ideas. Retrieved from https://www.researchgate.net/publication/31411638 1_Transgender_Issues_in_Pakistani_Community

5. Jaffery, Z. (1996). The Invisibles: A Tale of the Eunuchs of India: New York

6. Hoda, A. (2010). Accepting the Third Gender: Wordpress. HIV/AIDS and the Gendering of Stigma in Tamil Nadu, South India." Culture, Medicine and Psychiatry, 34, 633-657.

7. Reddy, G. (2005). With Respect to Sex: Negotiating Hijra Identity in South India. Chicago: University of Chicago Press.

8. Jami, H. (2005). 'Condition and Status of Hijras (Transgender, Transvestites etc.) in Pakistan (Country Report)', paper presented at the $1 \mathrm{st}$ International Conference: Gender and Sexualities, Bangkok, Thailand. Retrieved from https://openresearch-

repository.anu.edu.au/handle/1885/8669

9. Khan, A.A, N. Rehan, K. Qayyum., \& A. Khan. (2008). 'Correlates and Prevalence of HIV and Sexually Transmitted Infections among Hijras (Male Transgender) in Pakistan', International Journal of STD and AIDS, 19(12): 817-20.

10. National Center for Transgender Equality and the National Gay and Lesbian Task Force. (2011). Injustice at every turn. Retrieved from https://1map.com/endtransdiscriminationorg/ 
11. Khan, A.F. (2014). KhwajaSira: Culture, Identity Politics, and"Transgender" Activism in Pakistan, Syracuse University. Retrieved from http://surface.syr.edu/etd/56/

12. Joni. A, Cohan. (2018). Cis and Trans rights: two sides of the same coin. Tagged Women's StrikeInternational Women's Day Blog. Retriewed from https://www.versobooks.com/blogs/3667-cisand-trans-rights-two-sides-of-the-same-coin
13. Daniela, B., \& Devika, B. (2015). Regimes of Legalit: Enthography of Criminal Cases in South Asia. New Delhi: Oxford University.

14. Malik, Asad. (2012). "SC rules: Eunuchs have equal rights", Dawn. Retrieved from: https://www.dawn.com/news/752125/scruleseunuchs-have-equal-rights. 